\title{
Back to basics? Discourses of writing in Facebook groups for teachers
}

\author{
Erika Sturk, ${ }^{1 \star}$ Ann-Christin Randahl ${ }^{2}$ and Christina Olin-Scheller ${ }^{3}$ \\ ${ }^{1}$ Umeå University; ${ }^{2}$ Gothenburg University; ${ }^{3}$ Karlstad University
}

\begin{abstract}
This study investigates what discourses dominate teachers' beliefs about writing education and how these discourses are negotiated among teachers in social media. The empirical material is based on a stratified random sample of interactions, so-called threads, between teachers in three large open Facebook groups for teachers of Swedish (2,500-10,000 members). Taking Ivanič's 7 discourses of writing and learning to write as a framework, the study analyses discourses about writing visible in the interactions as well as blogs linked to, and school books and apps recommended. The two last steps are data-driven, emanating from previous steps. The result shows that $40 \%$ of the interactions concern writing. These interactions are dominated by a skills discourse. Further, a genre discourse challenges a former prominent discourse, the process discourse. Also, discourses in a social context are rare. The results indicate a narrow view of writing education in policy and practice, which, due to Ivanič (2004), can be interpreted as a consequence of a wider societal context where the educational system is questioned and explicit standards for writing are foregrounded. What conditions that would facilitate a wider range of discourses of writing in a school under pressure merits further investigations.
\end{abstract}

\section{Keywords: Literacy; discourses of writing; social media}

Responsible editor: Per Henning Uppstad

Received: November, 2019; Accepted: June, 2020; Published: September, 2020

\section{Introduction}

Over recent decades literacy has been a great concern in education. Global tests like PIRLS and PISA have brought about extensive programmes in schools, aiming at enhancing literacy. Though we are moving from a mass reading towards a mass writing society, literacy in school practice still focuses on reading education rather than writing education (Brandt, 2019). To foster participating members of a democratic society, Brandt argues, writing education is crucial. Different views or discourses of writing have dominated the policy level over the years and influenced

\footnotetext{
^Correspondence: Erika Stark, epost: erika.sturk@umu.se
} 
teaching practice. In a Swedish context a skills discourse historically dominated writing instruction (Bergöö, 2005). In the curriculum from 1969 and 1980, narrative and descriptive genres were put forward. Moreover, a process discourse was influential from the 1980's (Sturk \& Lindgren, 2019). Today, a genre discourse is prominent in policy documents. From a holistic view of writing education (Ivanič, 2004), pupils' writing development is promoted through a comprehensive and multifaceted practice. The aim of this study is to investigate to what extent a comprehensive writing education is prominent in teachers' talk about writing education. Two questions are raised: What discourses dominate teachers' beliefs about writing education, and how are these discourses negotiated among teachers (Ivanič, 2004, 2017)?

The setting chosen to investigate this, is social media. Today, social media is an important arena for professional discussions between teachers (Bergviken Rensfeldt, Hillman, \& Selwyn, 2018; Liljekvist, van Bommel, \& Olin-Scheller, 2017). The extended staff room, which is accessible on different platforms, has proven to offer teachers an effective community to ask for and offer help on daily issues in the classroom (c.f. Lantz-Andersson, Peterson, Hillman, Lundin, \& Bergviken Rensfeldt, 2017). Earlier studies have shown that teachers' interactions mainly concern teaching practice (van Bommel, Randahl, Liljekvist, \& Ruthven, 2020). In this study three large teacher Facebook groups, initiated and maintained by teachers themselves, are focused. The largest group attracts more than one quarter of all teachers in Swedish. Through this mapping the study can contribute to a fuller picture of common values and understandings of writing education among teachers and a point of departure to inform and develop practice.

\section{Theoretical framework and earlier studies}

When teachers discuss writing and how to teach and assess pupils' writing, their conscious or subconscious understandings about literacy are made visible. How to conceptualise these understandings, i.e. the notion of literacy, differs. Street (1984) suggests there is a distinction to be made between what he terms an autonomous view of literacy and an ideological view of literacy. This distinction, made salient within The New Literacy Studies, can shortly be described as a view on literacy as a decontextualized skill versus a view on literacy as a culturally situated social practice. The ideological perspective and power relations connected to different practices can be more or less foregrounded (Janks, 2010). From an ideological or social view of literacy, the communicative function is concerned, how individuals produce and reproduce meanings. The means we use to communicate are motivated, they are chosen to take a certain position in the given interactional context. Linguistic choices that individuals make, are made to cover certain meanings, in a certain way to achieve a certain effect (c.f. Karlsson, 2011). Within a multimodal community like the Facebook groups studied here, the mediational means can be both alphabetic letters, pictures, video clips and likes. 


\section{Discourses of writing}

A framework developed to analyse teachers' literacy practice and beliefs about writing education is Ivanič's discourses of writing and learning to write from 2004. In 2017 Ivanič expanded her framework with a new discourse, a discourse for thinking and learning (see Appendix 1). Ivanič defines discourses of writing as constellations of beliefs about writing; beliefs about learning to write/curriculum subjects; approaches to the teaching of writing/curriculum subjects; assessment criteria; and identity of the writer. In the following section the seven discourses are introduced. The order of the discourses follows Ivanič's framework, where different layers are focused in different discourses, beginning with the text and ending with the sociocultural and political context.

$A$ skills discourse has the text in the centre. Writing as a generic, context-free activity is the focus. Of importance is correctness rather than content. Further, writing and reading are mainly treated as separate skills in teaching practice, opposed to $a$ creativity discourse, where reading and writing are intimately related activities. Writing is about creativity, imagination and about becoming an author. Content and style are in focus and narrative texts common. In a discourse for thinking and learning, writing is used to clarify thoughts and learn school subjects. Pupils write to think, as opposed to a process discourse, where the cognitive process focuses on thinking and organising thoughts to write. It has developed into a methodology with mind maps, drafts, feedback, and revisions. In a genre discourse, conventional patterns for writing are identified. Teaching focuses on learning pupils to write different text-types, which are "linguistically appropriate to the purpose it is serving" (Ivanič, 2004, p. 233). In a social practices discourse, real-life contexts and the purpose of the communication are focused on. Pupils write to create meaning and to interact with a reader. In a sociopolitical discourse, the focus is on identity and power, and how to make one's voice heard in a democratic society. This discourse is closely connected to critical literacy (Clark \& Ivanič, 1999).

\section{Discourses of writing in school practice}

Earlier studies have used Ivanič's framework of discourses of writing and learning to write as an analytical tool to investigate school practice. In the following studies of teachers' perspectives and practice, studies of curricula, and studies of teaching materials are presented.

In studies of teaching practice, a skills discourse is prevalent (Lambirth, 2016; McCarthey, Woodard, \& Kang, 2014), together with a genre and a process discourse in compulsory school (Blikstad-Balas, 2018; Blikstad-Balas, Roe, \& Klette, 2018; Sturk \& Lindgren, 2019). Further, the lack of a socio-political discourse is emphasised. Earlier studies have also identified a negotiation of discourses in teachers' talk about practice and that teachers position themselves in a combination of discourses (McCarthey et al., 2014; Sturk \& Lindgren, 2019). This negotiation and positioning can be regarded as possibilities for agency, for both teachers and pupils (Holmberg 
\& Wirdenäs, 2010; Randahl, 2012). Randahl (2012) identifies a strong relationship between teachers' beliefs about writing education reported in interviews and their writing instructions observed in practice.

Studies of curricula reveal a predominance of a skills, a process and a genre discourse, but little evidence for a socio-political discourse (Peterson, 2012; Peterson, Parr, Lindgren, \& Kaufman, 2018). Magnusson (2019) describes a change in the view of writing education in policy documents in the lower grades, from a focus on narrative competence towards discursive writing. The current Swedish curricula focuses a genre approach stronger (c.f. Liberg, Wiksten Folkeryd, \& af Geijerstam, 2012), while earlier curricula have been skills and process oriented.

Writing in school is considered to be predominantly controlled by writing exercises: either teachers' own or exercises from teaching materials (Holten Kvistad \& Smemo, 2015). Magnusson (2019) suggests that school books can reflect how policy is implemented among teachers and in practice, since school books often are written by teachers. In a study of writing exercises in Norwegian school books from three decades, Veum (2015) uses Ivanič's framework. The results show a relatively small alteration over the years. However, a genre discourse and a social practices discourse are more visible in contemporary materials, whereas a creativity discourse is less visible in newer materials. A socio-political discourse is rare in the whole material. A conclusion is that writing exercises in school books need renewal, by for example using all Ivanič's discourses of writing for different aspects of writing (Veum, 2015). In a Swedish context Magnusson (2018) analysed 19 school books for grades 1-3 using Ivanič's framework, revealing that the process and genre discourses are common, and that there is a lack of social practices and socio-political discourses. In a study of teaching materials shared on an online forum, lektion.se, Gustafsson (2013) identified a domination of a skills discourse.

Investigating writing in school practice, policy documents and teaching materials using Ivanič's framework for discourses of writing has shown a strong focus on the text-focused writing discourses (a skills and a genre discourse), and a limited focus on context-focused writing (a social practices and a socio-political discourse).

\section{Setting, material and method}

In this study Ivanič's framework is used to examine a rather new setting, social media. What possibilities and constraints social media as a setting implicate are elaborated on in the following section. Further, the analytic procedure is described.

\section{Social media as setting}

Social media has become an important part of teachers' professional lives. In particular, Facebook groups created and maintained by teachers themselves have proven to offer teachers an extended staffroom, where teaching material is shared and questions about practice are answered (Kelly \& Antonio, 2016; Randahl, Olin-Scheller, 
van Bommel, \& Liljekvist, 2017; Randahl, 2018). Studies of interactional patterns in Facebook groups reveal that more than $85 \%$ of the posts get response. The most common response to an offer (e.g. of teaching material, lesson plans) is a "like". Participating teachers emphasise how such groups support their professional development (Duncan-Howell, 2010). Due to the focus on mutual or collective development, teacher Facebook groups can be regarded as professional learning communities (PLCs). Previous studies on online networks have affirmed key features of PLCs identified by Stoll et al. (2006). For example, a collective responsibility to share ideas for teaching (Ranieri, Manca, \& Fini, 2012), an inclusive membership with low barriers for participation, mutual trust and respect, where teachers dare to take risks and ask questions they "should" know (Lantz-Andersson et al., 2017).

Studying this new arena allows researchers to be the fly on the wall, able to attend to what is said in this huge staffroom. Though, the setting requires specific ethical considerations, first and foremost regarding anonymity. To protect the teachers' identity, there are no quotations from posts published. Since excerpts from data have been slightly reformulated and translated from Swedish to English, they are no longer directly searchable. Neither are the names of the three teacher Facebook groups revealed. Instead they are labelled Swe1, Swe2, and Swe3. The study was approved by the Regional Ethical Review, without any demands on consent from participating members. Due to the size of the groups, the members arguably would consider the group as a public space, and act in accordance with that (Roberts, 2015). However, we informed the administrators about our data collection. Finally, it should be noticed that interaction in this kind of data is in a constant flux; links can be removed and web pages and platforms closed.

\section{The Facebook material}

The material consists of interactions, so-called threads, between teachers in three large open Facebook groups, including from 2,500 members to 10,000 members.

The data used is based on a stratified random sample of approximately 100 posts and comments per group. In social media, liking is a common means to make a comment. Therefore, liking is included in the sample. The platform as such enables the user to attach different resources, such as documents and pictures. There is also a possibility to link to other web pages. This type of material is captured too. The result of the stratification process is compiled in Table 1.

Table 1. Overview of data.

\begin{tabular}{lcccccc}
\hline Group & Posts & Comments & Likes & Documents & Pictures & Links \\
\hline Swe 1 & 83 & 623 & $1279(708)$ & 3 & 4 & 71 \\
Swe 2 & 107 & 917 & $1666(1191)$ & 6 & 9 & 91 \\
Swe 3 & 96 & 276 & $534(173)$ & 1 & 11 & 45 \\
\hline Total & 286 & 1816 & $3479(2072)$ & 10 & 24 & 207 \\
\hline
\end{tabular}




\section{Method}

In this study we regard teachers' utterances as influenced by different factors. On an institutional level subject traditions, school books, and policy documents might guide the teachers' views about writing education. Further, teachers' views are influenced by school culture, colleagues, pupils, and organisation of practice (c.f. Smidt, 2010). To investigate what discourses of writing education are made relevant in teachers' interactions in the extended staffroom, the material was analysed in four steps: identifying threads about writing education, analysing discourses visible in the interactions, analysing school books and apps, and analysing blogs. The two last steps are data-driven, emanating from previous steps. The analyses were conducted by two researchers.

In a first step an analysis was undertaken on a macro level to identify threads concerning writing education. In total 118 threads (40\%) were identified, where writing education, either partly or completely dominated the threads. Out of these, 14 threads focused only on upper secondary teaching, and were therefore considered irrelevant in this study, resulting in 104 threads. In a Swedish context, the subject area of Swedish is divided in two: Swedish as L1 and Swedish as L2. To enable a comparison between discourses of writing education in the subject areas of Swedish as L1 and L2, threads concerning Swedish as L2 were marked. Finally, the material was categorised in relation to school form, regardless of Facebook group, resulting in following categories: grades $1-3$, grades $4-6$, grades $7-9$, and all grades.

In a second step, a discourse analysis of the 104 threads was carried out, aiming at finding different positions made visible in the interactions. In this analysis, each instance was counted. Typically a post or comment embraced one discourse, in few cases more discourses were visible. Further, additional means in the interactions were included in the analysis. In the 104 threads, there are 4 documents, 5 pictures, and 41 links analysed. Supportive actions such as "liking" are not included in the discourse analysis, but commented upon due to the findings. The analysis was crosschecked discourse by discourse, resulting in 9 changes. These changes were spread over discourses and over the material.

To illustrate the analytic process, one thread is presented (see Table 2). Four teachers participate in this interaction. In the first post, 1277 raises a question. This question is followed by six comments. In the third column additional means are captured, in this interaction represented by likes and links. One link was removed and could not be analysed. In the fourth column the analysis of the discourses of writing visible in the post and comments is noted. The post and one comment are interpreted as visualising a genre discourse: the first asks for a model text for blogs, the other describes how these model texts have helped the pupils to write. The three comments concerning blogs, where pupils write in real-life contexts for real purposes, are interpreted as visualising a social practices discourse. 
Table 2. Analysis of a thread.

\begin{tabular}{|c|c|c|c|}
\hline ID & Post and comments & $\begin{array}{l}\text { Additional } \\
\text { means }\end{array}$ & $\begin{array}{l}\text { Discourse of } \\
\text { writing visible }\end{array}$ \\
\hline 1277 & $\begin{array}{l}\text { Hi! We use the school book X. In the previous chapter we } \\
\text { read about blogs, and today we talked about what blogs are. } \\
\text { I presented two blogs, but they were rather difficult for the } \\
\text { pupils to understand. My question is whether someone has } \\
\text { tips on blogs, which are easy to read. }\end{array}$ & & Genre discourse \\
\hline 1278 & Following ... we are also going to work with that chapter. & & \\
\hline 1279 & $\begin{array}{l}\text { Read our blog! It is a school blog, where pupils and teachers } \\
\text { write about our school. }\end{array}$ & $\begin{array}{l}\text { Link to school } \\
\text { blog } 1 \text { like }\end{array}$ & $\begin{array}{l}\text { Social practices } \\
\text { discourse }\end{array}$ \\
\hline 1278 & Follow our pupil on the blog of his sport team! & $\begin{array}{l}\text { Link to blog } \\
1 \text { like }\end{array}$ & Link missing \\
\hline 1277 & $\begin{array}{l}\text { Nice blog (1279)! What do your pupils think about having the } \\
\text { blog public? What domains have you used? Only give answers if } \\
\text { you have time }-\end{array}$ & & $\begin{array}{l}\text { Social practices } \\
\text { discourse }\end{array}$ \\
\hline 2765 & $\begin{array}{l}\text { Thanks }(1279)-\text { Nice to have more blogs to show my pupils. } \\
\text { We talked about the text in the school book, and suddenly my } \\
\text { pupils said: "We want to write now". They wrote wonderful } \\
\text { "blogs". They learnt that a blog is a text in social media. }\end{array}$ & & Genre discourse \\
\hline 1279 & $\begin{array}{l}\text { Thanks } 1277 \text { ! We also like our blog. When starting it we were } \\
\text { not sure whether our blog should be public or not, but we didn't } \\
\text { need to hesitate: almost all our pupils think it is fun and cool that } \\
\text { so many can read what they write. The pupils use their blogs for } \\
\text { school assignments - and, if they want to, for private use as well. } \\
\text { We used the platform X for our school blog. They have good } \\
\text { instructions. Good luck - hope you start blogging soon! })\end{array}$ & 1 like $\bullet$ & $\begin{array}{l}\text { Social practices } \\
\text { discourse }\end{array}$ \\
\hline
\end{tabular}

In a third step, all school books and apps that the teachers recommend for writing instruction, were analysed. In total 23 school books (see Appendix 2), and 16 apps. The decision to include this analysis in the study is two-fold. First, interactions where teachers ask for advice regarding teaching material are the most common topic in the overall dataset. Second, to be able to reveal prominent discourses in these interactions, it was necessary to analyse the material recommended. Moreover, teaching material like school books and apps can reflect how policy is implemented (Magnusson, 2019). To analyse school books, the researchers constructed a scale, to evaluate to what extent different discourses are more or less prominent (see Appendix 3). The units for analysis were exercises including writing in the entire books, also, teacher instructions material was analysed on a word level. Two researchers analysed and coded 18 school books, first separately, then discussed and agreed upon. Thereafter one researcher coded the remaining 5.The apps were analysed by one researcher, then discussed and agreed upon. To illustrate the analytic process, examples of discourses visible in school books' exercises are presented (see Table 3). A skills discourse is 


\section{E. Sturk, A.-C. Randahl E C. Olin-Scheller}

exemplified by a grammar exercise, while a creativity discourse, in which reading and writing are closely connected (Ivanič, 2004), is exemplified by an exercise inviting the pupils to use their imagination to write. A discourse for thinking and learning has two examples of exercises: one for writing to think, and one for writing to learn. A process discourse is exemplified by a mind map exercise, and a genre discourse is exemplified by writing a special text-type. A social practices discourse is exemplified by a writing exercise with the classroom as social setting affording opportunity for purposeful communication (Ivanič, 2004). Finally, a socio-political discourse is exemplified by a normative exercise about gender.

Table 3. Analysis of school books' exercises.

\begin{tabular}{|c|c|c|c|c|c|}
\hline \multicolumn{4}{|c|}{ Exercise } & $\begin{array}{l}\text { Discourse of } \\
\text { writing visible }\end{array}$ & $\begin{array}{l}\text { School book } \\
\text { (see Appendix 2) }\end{array}$ \\
\hline \multicolumn{4}{|c|}{ Write the nouns and create comparison. } & A skills discourse & Språkskrinet \\
\hline En/ett & Flera & Den/det & De/dom & & \\
\hline stol & stolar & stolen & stolarna & & \\
\hline
\end{tabular}

Write a fiction story about someone who survives on their own. Remember to write an enthralling story! (Exercise preceded by reading Robinsonades.)

How do you learn best?

Explain the words from the text: market, product, service, convince ...

Mind map

A mind map with keywords is useful when you write facts. The mind map helps you to remember what to write about. Draw a mind map about the cat.

You are going to write a salad recipe. A recipe is an instructive text, telling someone how to do something.

Use the recipe at page 135 when you write.

Write your factual texts and put on the classroom wall so that others can read it.

Why, do you think, all girls want to be Lucia? Do you think that boys also can be Lucia? Why?
A creativity discourse Kom i gång!

A discourse for Prima svenska
thinking and learning

A process discourse $\quad$ Forma språket

A genre discourse Fördel

A social practices Prima discourse

A socio-political Läs med oss (copy discourse material)

In teacher Facebook groups like these studied here, there are key persons contributing more often with posts and comments (Prestridge, 2019). Among this group of key persons, there are bloggers, linking to their own blogs or recommending others'. In the analysis of posts and comments a total of 32 blog posts from 14 bloggers concerning writing education, were identified. These blogs were sorted out and analysed separately in a fourth step. 


\section{Findings}

In the following sections our main findings are presented. First, the discourses of writing dominating teachers' beliefs about writing education are described - both how they are distributed in the data, and with examples from the data. Second, how these discourses are negotiated, or not, is focused.

\section{Distribution of discourses of writing}

In the data, all seven discourses are made visible, though, some discourses are visible to a limited extent whilst other discourses are dominating the interactions. To summarise (see Table 4), the most prominent discourses in the interactions are a skills discourse (78 posts) and a genre discourse (53 posts), followed by a creativity discourse (42 posts), a discourse for thinking and learning (31 posts), a process discourse (19 posts) and a social practices discourse (19 posts). There is a lack of a socio-political discourse in the interactions - only two instances were found in grades 7-9. Most interactions concern writing in grades $7-9 /$ all (85/84 posts), and grades $1-3$ ( 65 posts), whereas interactions concerning writing in grades $4-6$ are rare (10 posts).

The table also shows the distribution of discourses visible in interactions concerning Swedish as L2, revealing that the dominating discourse is a skills discourse (23 posts), followed by a creativity discourse (17 posts), a discourse for thinking and learning and a genre discourse (16 posts each). Further, there is a lack of a social practices and a total lack of a socio-political discourse. This finding follows the overall pattern, but in interactions concerning Swedish as L2, a creativity discourse is present to a higher extent. However, all instances are found in three threads, while other discourses are distributed over more threads.

Table 4. Distribution of discourses of writing visible in the Facebook material.

\begin{tabular}{|c|c|c|c|c|c|c|c|c|}
\hline Grades & $\begin{array}{c}\text { A skills } \\
\text { discourse }\end{array}$ & $\begin{array}{c}\text { A } \\
\text { creativity } \\
\text { discourse }\end{array}$ & $\begin{array}{c}\text { A } \\
\text { discourse } \\
\text { for } \\
\text { thinking } \\
\text { and } \\
\text { learning }\end{array}$ & $\begin{array}{l}\text { A process } \\
\text { discourse }\end{array}$ & $\begin{array}{c}\text { A genre } \\
\text { discourse }\end{array}$ & $\begin{array}{c}\text { A social } \\
\text { practices } \\
\text { discourse }\end{array}$ & $\begin{array}{l}\text { A socio- } \\
\text { political } \\
\text { discourse }\end{array}$ & Sum \\
\hline \multicolumn{9}{|l|}{ FB total } \\
\hline All & 34 & 6 & 12 & 6 & 22 & 4 & 0 & 84 \\
\hline $1-3$ & 31 & 10 & 2 & 7 & 8 & 7 & 0 & 65 \\
\hline $4-6$ & 2 & 6 & 0 & 1 & 0 & 1 & 0 & 10 \\
\hline $7-9$ & 11 & 20 & 17 & 5 & 23 & 7 & 2 & 85 \\
\hline Total & 78 & 42 & 31 & 19 & 53 & 19 & 2 & 244 \\
\hline $\begin{array}{l}\text { Out of which } \\
\text { concerns L2 }\end{array}$ & 23 & 17 & 16 & 4 & 16 & 4 & 0 & 81 \\
\hline
\end{tabular}




\section{E. Sturk, A.-C. Randahl E C. Olin-Scheller}

The analysis of school books (see Figure 1) reveals that discourses of writing education are unequally privileged in the material. A skills discourse is the dominating discourse in 15 school books, followed by a process and a genre discourse (4 times each), and a creativity discourse (3 times). There are no school books dominated by a thinking and learning, social practices or socio-political discourse.

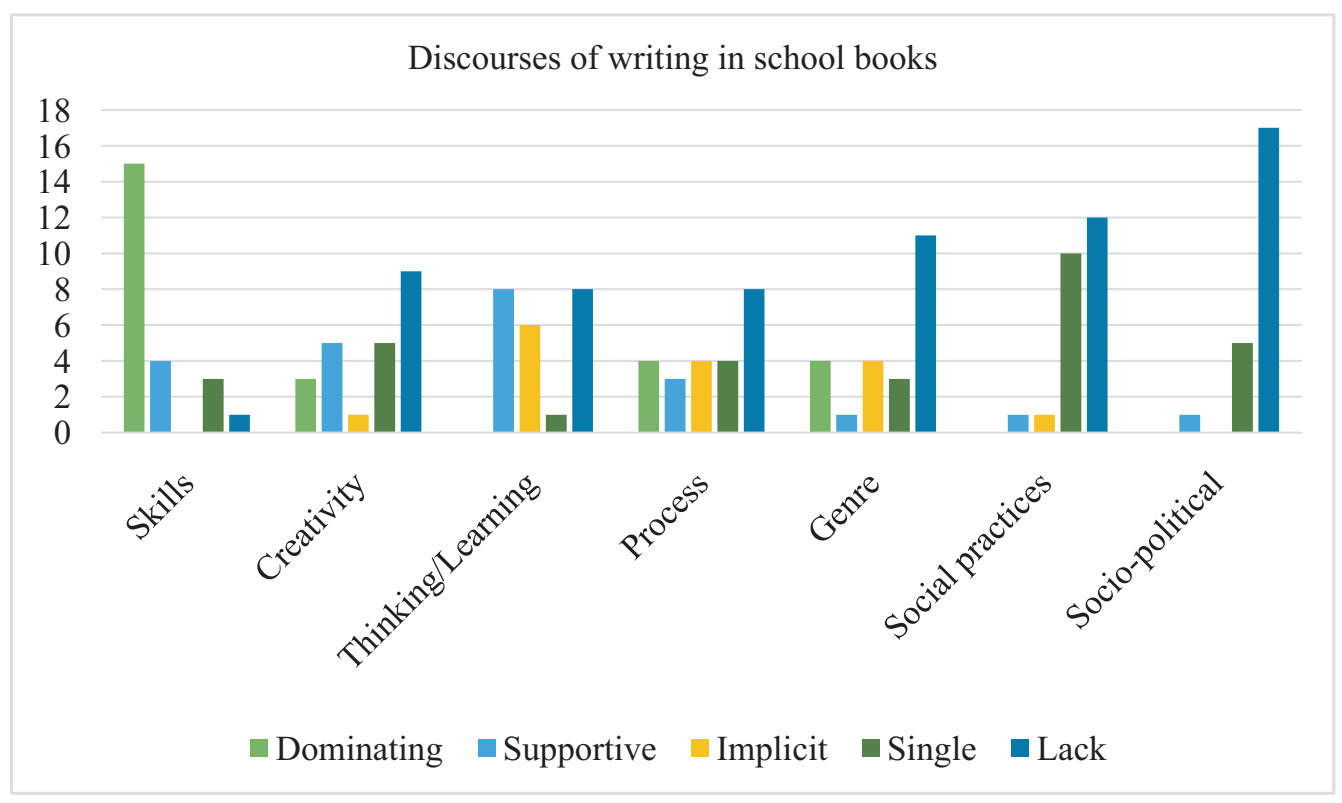

Figure 1. Distribution of discourses of writing visible in the school books.

Most of the school books analysed (19/23) represent more than one discourse. Generally, one discourse is dominant and the others are supportive, implicit or single represented. Four school books only represent one dominating discourse, a skills discourse, without any supportive, implicit or single discourses. In some books, pedagogy emanating from different discourses seem to negotiate or merge. This is visualised in figure 2, taken from the same chapter in a school book (Stensson, 2016a, p. $83 ; 2016 b$, p. 73). On the first page, a text is modelled and words and linguistics patterns for the genre are displayed - implying a genre discourse. On the second page, the model text remains, scaffolded by a mind map, and in further exercises, the pupils are asked to write a text using a mind map for planning, following a process discourse of writing instruction.

Like the school books analysed, the apps that teachers give suggestions on are dominated by a skills discourse (see Figure 3). Though it is a limited selection, the apps discussed in the forum do not meet a comprehensive writing education - only three discourses were identified. 


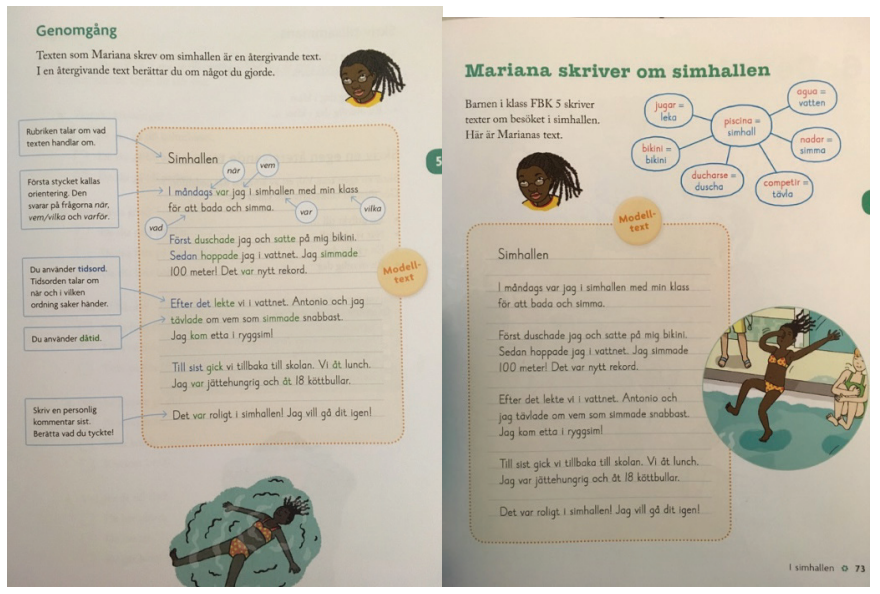

Figure 2. Pictures from the school book Fördel. Author H. Stensson, illustrator S. Reuterskiöld.

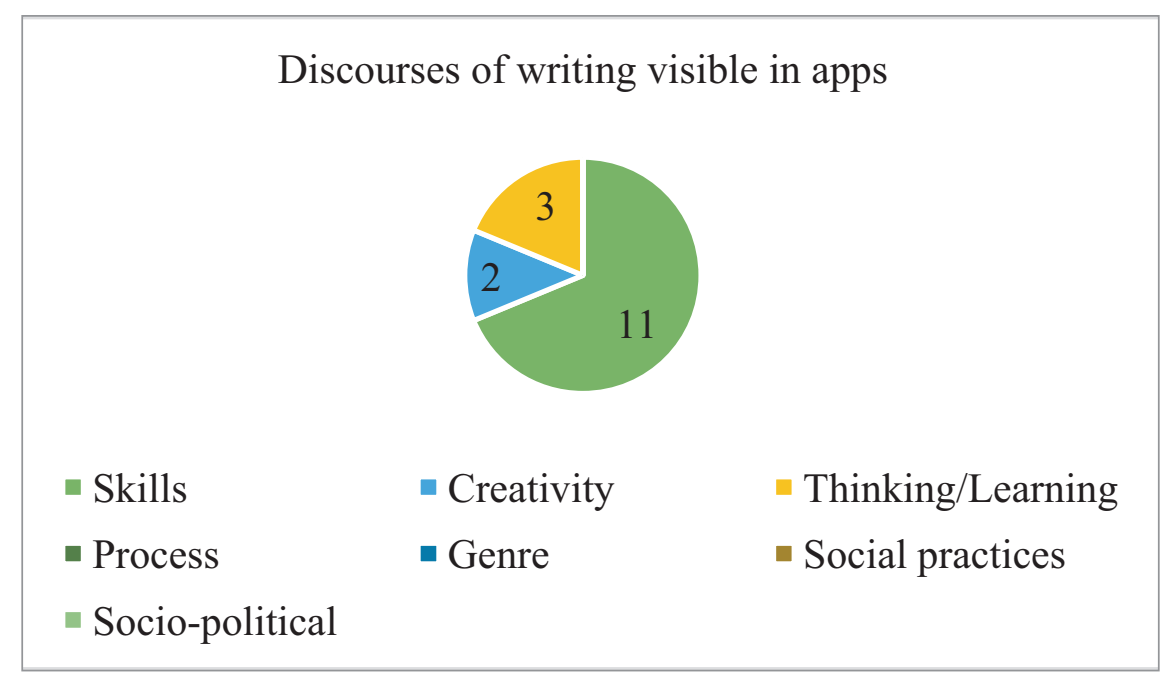

Figure 3. Discourses of writing visible in the apps.

The analysis of the 32 blogs reveals a slightly different pattern, where the distribution of dominating discourses is a bit wider. A skills, a genre, a social practices, and a creativity discourse are equally common, whilst there is a lack of a discourse for thinking and learning and a socio-political discourse in the blogs (see Figure 4).

Blogs are often commented upon via "likes". Actually, half of the interactions with most "likes" concern blogs, indicating that bloggers' beliefs about writing education are supported by other members in the groups. 


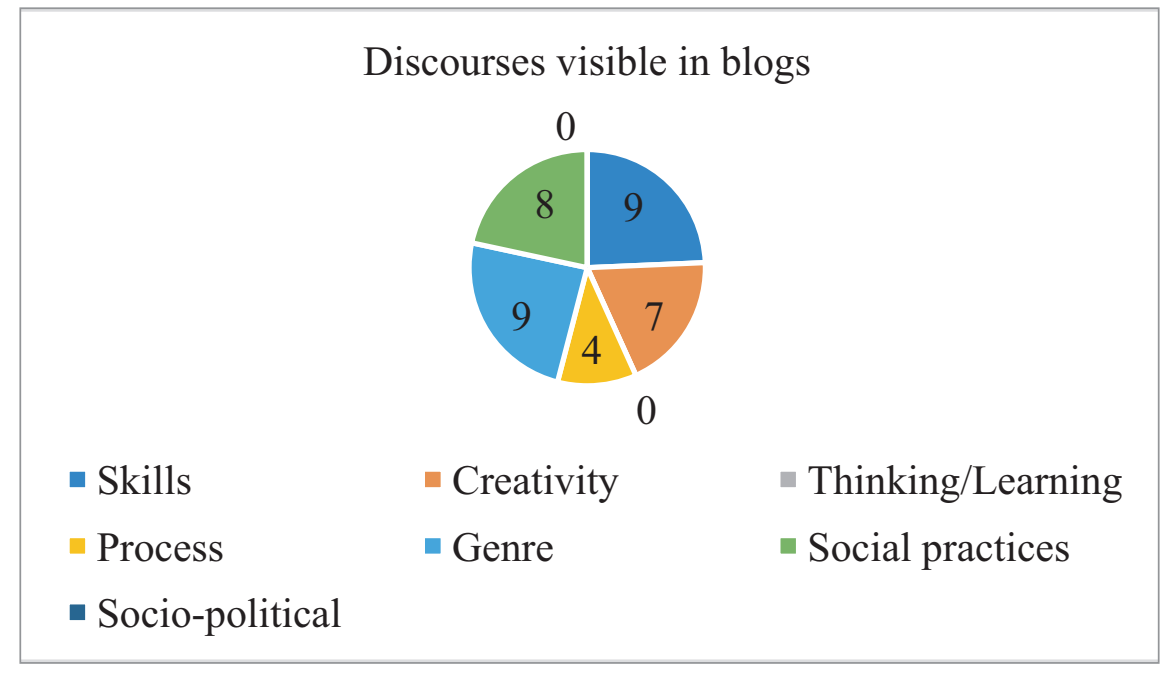

Figure 4. Distribution of discourses of writing visible in the blogs.

Looked upon from the context of the subject area of Swedish as L1, the results indicate a return to a dominating skills discourse. So, are we back to what Bergöö (2005) describes as teaching basic skills?

\section{Examples of discourses of writing}

In the following section, the discourses identified in the material are visualised by examples. It is sectioned in order with the most predominant discourse of writing first.

A skills discourse is prevalent in interactions about assessment and National Tests, or when teachers talk about spelling and grammar (Ex. 1).

Ex. 1 - Do you have any suggestions on exercises for my class during the weeks leading up to summer?

- Writing rules! :-) Fun! Takes no time correcting ...

Documents, pictures and links visualising this discourse include grammar instructions and exercises, jokes about grammar (30 v), and essays. School books focusing writing as a skill, contain exercises about forming letters, handwriting, spelling and grammar.

Though a skills discourse is predominant in the Facebook groups overall, there is a tendency that the importance of the discourse decreases in higher grades.

A genre discourse is visible in teachers' explicit references to genre pedagogy (Ex. 2 and 3). It can also be seen in posts, where teachers explain how they work with e.g. a special text-type (Ex. 4). 
Ex. 2 - I'm making attempts to apply genre pedagogy.

Ex. 3 - On my blog you can read about how we work with the circle model. (81४)

Ex. 4 - I am teaching a grade 2 class, and I want to join the trend with pen friends, adding a twist: I want my class to have a pen friend class, and that we write emails together on the computer and projector. In that way the pupils can see the text grow, and we can talk about form, language and vocabulary ...

Documents and links contain for example an attached booklet about genres (72 ) , an instructional YouTube film on comparative analysis (21 $)$. Blogs concerning Swedish as L2 often take a position related to a genre discourse.

In teaching material, a genre discourse is most visible in materials for higher ages, preferably in Swedish as L2. Examples are found in school books building on a genre approach and the circle model to support pupils in learning to write different text-types. Concerning writing and learning to write within a genre discourse Ivanič (2004) writes: "The 'target' text-types are modelled, linguistic terminology is taught" (Ivanič, 2004, p. 232). Still, in L1 teaching material with an L1 norm there is seldom focus on the written language in the different genres, and modelling of text-types quite uncommon.

A creativity discourse is for example visible in teachers' talk about the pupils creating books (Ex. 5), and writing for creativity (Ex. 6).

Ex. 5 - In my $6^{\text {th }}$ grade we are producing an ABC-book with alliterations. They illustrate and write - and they love it!

Ex. 6 - You have the texts in your pupils ... not too important with form, just get them started writing.

A creativity discourse is visible in pictures, shared and recommended as writing inspiration to the pupils. One teacher writes to the picture posted that it stimulates pupils' fantasy (Ex. 7):

Ex. 7 - Dreams can take you anywhere; this wonderful picture brings you and your pupils to a world of fantasy.

Approaches to the teaching of writing within a creativity discourse involve "treating learner writers as 'authors"' (Ivanič, 2004, p. 229). One app analysed as a creativity discourse concerns creating books online. In school books, pupils are positioned as future authors, e.g.: "Dramaturgy opens the door to storytelling, existing in every human being, to the talent waiting to be released" (Grönte, 2013, p. 11). Grönte also expresses the need for the teachers to be writing models for their pupils. However, in most school books this kind of writing mainly exists as extra exercises. 
A discourse for thinking and learning is visible in teachers' interactions about when the pupils write to learn, e.g. in weekly diaries, writing logs, taking notes (Ex. 8). Learning Swedish as a subject, first and foremost emphasises learning to read literature in a specific manner (Ex. 9). Learning Swedish as L2 puts language development at the centre. Giving pupils opportunity to use all their languages, often described as translanguaging, is seen as an important means to promote linguistic competence (Ex. 10). Further, exercises to expand the pupil's vocabulary are common (Ex. 11).

Ex. 8 - Many of my pupils want notebooks in order to take notes and write translations.

Ex. 9 - Write a short section about the story of the book, then analyse ...

Ex. 10 - Ask the pupils to use their L1, write common phrases and translations. Put these on the classroom wall and ask the pupils to compare the languages and find similarities and differences.

Ex. 11 - Write classroom words on Post-its: ceiling, window, door ... Repeat!

This discourse is two-fold: a discourse for thinking and for learning. In school books, when thinking is focused, pupils are using writing as a tool for self-reflections, common in exercises where the pupils write logs, "Where am I, where am I going?", and write reflections about what they have learnt relative to these goals. When learning is focused, the content of the subject is foregrounded. Exercises on reading comprehension, concerning how to approach and analyse films and books are frequent, including questions like "Have you understood the text you read?"

A process discourse is visible, for example in interactions about how to organise formative responses. In example 12 pair assessment is discussed.

Ex. 12 - How do you work on self-assessment of stories? We have pair assessment with two stars and a wish.

- Pair assessment!

- Checklists after presentations of different aspects: people and environment descriptions.

- We work with feedback, pupil to pupil. The pupils write their first draft and improve their text.

In school books this discourse is manifested through the writing process approach. The pupils are encouraged to plan their texts with mind maps, to write drafts and to ask classmates to read and revise their texts.

A social practices discourse is common in teachers' talk about how they arrange writing exercises, where the pupils write for readers outside school (Ex. 13, 14, 15, and 16). Further, analysed as a social practices discourse are posts from teachers creating a community in their classroom (Ex. 17). 
Ex. 13 - When we upload on YouTube, the pupils can show at home what they did at school.

Ex. 14 - We work with Twitter in our class.

Ex. 15 - We run a school blog.

Ex. 16 - We made an interview with a famous author of children' books - read our blog about how we wrote our questions!

Ex. 17 - Let your pupils make instruction films using digital tools!

A social practices discourse is visible in links, such as school blogs, and a picture showing a map over a city where the teacher is looking for pen friends for her pupils. In a former example penfriends and letter writing was analysed as a genre discourse, since the teacher's core focus was on learning to master the genre, not to get readers. In blogs a social practices discourse is visualised through the bloggers' attempt to offer the pupils a context, for example a school blog, with a purpose for writing.

In school books there is mostly a lack of the social practices discourse, but it can be found in exercises organising exhibitions, or writing weekly letter home. There is also an online material recommended (49 $)$ ), where the pupils can publish their texts online on the website. In one exercise pupils are encouraged to write on "Fakebook", as a character.

There are only two examples of a socio-political discourse in the teachers' interactions (Ex. 18 and 19). In example 18 an analysis of media's way of reporting precedes the writing, indicating an intention to awake critical language awareness (Ivanič, 2004). Example 19 concerns reflections on norms and identity.

Ex. 18 - How do you work with the refugee crisis?

- We are analysing pictures from a photographer on the Hungarian border, and media's different ways of reporting the crisis. The pupils write their own contribution to the debate in a chronicle.

Ex. 19 - We write comparative texts about Elling and The Ugly Duckling, and reflect upon norms and alienation.

In the school books in all grades a socio-political discourse is visible in single exercises, mostly after reading texts where dilemmas are raised (Ex. 20 and 21) or pupils are promoted to reflect on questions concerning identity (Ex. 22). In one school book for grades 7-9, for Swedish as L2, Swedish becomes a subject for democracy, underlining why democracy and equality are important, and what channels citizens have to express their opinions.

Ex. 20 "Can you look different on the outside and the inside? What do you think?"

Ex. 21 "John's dad is in prison. What do you think he has done?"

Ex. 22 "Look at the picture: What do you think; is it a boy's or a girl's room? Discuss with a friend. Explain why you think as you do. Write in your notebook!" 


\section{E. Sturk, A.-C. Randahl \& C. Olin-Scheller}

\section{Negotiating discourses of writing education in social media}

The results show that some discourses are dominant and some are rare in teachers' beliefs about writing education. This pattern is shaped through interaction. How discourses are negotiated, is focused in this section.

A negotiation might indicate tensions between different discourses in the interactions. However, the common pattern is that the teachers take the same position, rather than arguing about different views of writing. In example 23 the teachers position themselves in a genre discourse. The teacher starting up the thread also adds a resource, a help pamphlet about text-types.

Ex. 23 - Scaffolding helps the pupils - I believe in the idea of help pamphlets. Here is one made for text-types in Swedish. Also, a book tip: Fix the genre, Let the language carry (genre pedagogy).

- Have you seen Per Holmberg's and Anniqa Sandell Ring's books?

- Thank you for the inspiration! I need to update my stone age teacher exam!

- It is hard for the pupils to build texts with a determined purpose. Therefore we need material like the one you've created.

This thread includes a lot of exalted exclamations, such as "Wonderful! Now I'm inspired", "Marvellous!”, "Really good!”, "Impressive! Plain and simple!”, "Fantastic! Thank you!", "Wow", and in addition 72 "likes" $\vee$. This kind of minimum response is common in interactions where teachers offer something. In the context of social media a like is equivalent to a comment (Randahl, 2018). In our understanding, therefore such responses strengthen the position of the discourse.

There are also interactions, where teachers take different positions. In example 24, four different discourses are identified: a genre discourse (genre pedagogy), a process discourse (the process approach), a social practices discourse (recipes) and a creativity discourse (writing to pictures). However, no tensions between different positionings are visible. Instead, different discourses appear side by side.

Ex. 24 - Do you have any suggestions or ideas for a summer school, grades 4-9? Grateful for creative suggestions concerning content and methods.

- Genre pedagogy!

- I always work in line with the process approach.

- Work thematically and use real-life experiences. For example, cooking - read and write recipes ...

- We take a lot of pictures and write about them.

- We have also written to pictures. Once we wrote a complete book about life at summer school.

- How exciting!

- Yes, the book was nice! 
What differentiates this interaction from the previous one, is the introduction of the thread. In our data, a question more often opens up for different positionings, whereas a distinct positioning in the introduction of a thread is likely to be reinforced in following comments.

To summarise, there are few examples where discourses are negotiated. Teachers seem not to question a position taken by colleagues. In our data there are only two examples of this, both related to assessment where a skills discourse is questioned. In one of these interactions, concerning the word limit on the National Tests, a teacher questions the assessment criteria: "A pupil with a well-written text does not pass the test because he has surpassed the maximum number of words ... What view does the pupil get of writing?" However, our data consists of interactions within large Facebook groups for teachers - interactional patterns might be different within smaller groups. Such studies would complement the picture of negotiation.

\section{Discussion}

When teachers interact in the Facebook groups studied, writing education is an important issue. $40 \%$ of the interactions concern this matter. In this extended staffroom discourses of writing are made visible. The results show that a skills discourse dominate the interactions and that a genre discourse challenges a former prominent discourse, a process discourse. How this dominance can be understood will be discussed in relation to a wider school context and contrasted to less prominent discourses - the creativity, social practices and socio-political discourses. Further, Ivanič's new discourse for thinking and learning is elaborated on.

A major concern that arises, is how to interpret the dominance of a skills discourse in relation to decades of writing methodologies informed by a process, a creativity, and a genre discourse (Liberg et al., 2012). There are different answers: In times where current school system is under pressure, a skills discourse is foregrounded (Ivanič, 2004). In Sweden, pupils' performance in large scale assessments like PISA has declined (dramatically). As a consequence, Sweden is recommended to focus on basic skills: "Preventive approaches should also be enhanced to ensure that all students consolidate basic skills from early stages onwards" (OECD, 2015, p. 8). One can understand this as a pressure put on teachers to perform a specific kind of writing education. Krogh and Penne (2015) state: "in Scandinavian countries, an adaption to the OECD educational policies - including the testing system - has led to a pragmatic turn towards skills and literacy in the L1 subjects" (p. 4). The result raises questions about teachers' agency and what conditions would facilitate a wider range of discourses of writing education in the current system. Further, a skills discourse is to a different extent prevalent in teachers' norms when assessment of text is focused (c.f. Solheim \& Matre, 2014). In the data, this circumstance is noted in interactions about National Tests. A skills discourse also seems to be relatively easy to connect to a genre discourse. Walldén (2019) shows how writing education informed 
by a genre discourse can take on a normative perspective, where accuracy in relation to text structure is focused. One can also raise questions about how digitalisation may influence writing education. The apps recommended by teachers have a strong focus on skills. To what extent these apps are representative in relation to what teachers are offered when searching for ways to use tablets and fulfil policy on digitalisation, needs further investigation.

The dominance of specific discourses in the teacher Facebook groups might also be connected to the setting. It seems as if teachers' positionings are reinforced rather than questioned, due to interactional norms of social media. Further, the role of key persons in the community, in this study represented by the bloggers, seems to influence the dominating discourses. The blogs analysed are mainly related to a skills and a genre discourse. The latter is prevalent in blogs where writing education in Swedish as L2 is foregrounded. However, blogs informed by a creativity or a social practices discourse are also relatively common. In particular one can pay attention to the instances where a social practices discourse is visible. Teachers interacting via social media seem to transfer this practice into the writing education, for example by supporting pupils to write blogs.

Also school books recommended are important to understand what discourses dominate teachers' beliefs about writing education (Magnusson, 2019; Selander, 2004; Smidt, 2010). Besides a dominating skills discourse it is also possible to trace a struggle between two different methodologies informed by a process discourse and a genre discourse. In this struggle, the process discourse seems to decline in favour of a genre approach (c.f. Veum, 2015). This can also be related to the policy level in Sweden (Liberg et al., 2012).

In the social media setting there is a movement towards a social practices discourse, but, in accordance with previous studies, instances concerning a socio-political discourse of writing are rare (Lambirth, 2016; McCarthey et al., 2014; Peterson et al., 2018). That might reveal a teaching practice where the communicative context and writing related to power and identity are downplayed. Still, this is needed in a democratic society to foster participating members (Brandt, 2019) so they can make their voices heard.

In writing research, writing proficiency is regarded as a multifaceted competence (c.f. Evensen, 2007). A strong dominance of a skills discourse in writing education, runs the risk to neglect this complexity and context dependency of writing and writing development, since it rests on a view of writing as a single, general competence. Therefore, to create a comprehensive writing education, Ivanič (2004) suggests that teachers benefit from knowing about different discourses of writing and the pedagogic practices connected to them, and compensate for curricula, where single discourses dominate. In the Swedish context, narrative writing is declining at the expense of discursive writing (Magnusson, 2019). Though it is the third most visible discourse, it mostly appears as extra exercises in the school books, implicating creative writing is something for the more fluent writers. Moreover, expanding the framework Ivanič 
(2017) opened up for the possibility for additional discourses, which need to be further investigated in relation to a comprehensive writing education.

A last issue concerns how to identify and interpret Ivanič's discourse for thinking and learning. First, the discourse seems to be two-fold. Thinking is connected to the cognitive layer in Ivanič's model. This part of the discourse is visible in writing assignments for reflection and self-assessment. Learning is related to disciplinary literacy, and focuses on the content of the current school subject. In line with Sturk and Lindgren (2019), this discourse appears above all in interactions concerning grades 7-9. This might be explained by a stronger focus on the content as such. Writing to learn the discipline, we suggest, is visible in a common writing assignment where pupils are supposed to interpret different kinds of literature. In our understanding, writing these assignments is a way to foster a specific art of reading, which is valued within the discipline. In assignments where ethical questions are raised, or where pupils are supposed to take a stand in relation to the text read, a discourse for thinking and learning seems to inhabit features close to a socio-political discourse.

Teachers' interactions about writing education can reflect their practice (Randahl, 2012), and our results show that, among members in Facebook groups for teachers, enhancing literacy can be a movement both forward, to a social practices writing discourse, and back to basics, adhering a skills discourse. We suggest that these movements should be seen in the wider context of society, where teaching practices are closely linked to aspects of policies such as national policy documents, but also local school culture, colleagues and pupils. Changes in society at large affect policy and practice. However, writing education is part of forming citizens. Therefore, to give pupils tools, self-confidence, motivation and identity of writers, encouraging them to make their voices heard, a multifaceted and comprehensive writing education is crucial.

\section{Acknowledgements}

This study is a part of the project Teachers' Professional Development on Facebook (Dnr 2015:01979), founded by the Swedish Research Council. It is also partly founded by the Kempe foundation.

\section{Author biography}

Erika Sturk is a PhD student and a teacher educator at the Department of Language Studies at Umeå University, Sweden. She has a background as a teacher in Swedish (L1 and L2) and English, and as a coordinator of local and regional literacy networks for teachers. Her research interests include writing education and discourses of writing in policy and practice.

Ann-Christin Randahl has a position as senior lecturer in Swedish with specialization in didactics at the Department of Swedish at Gothenburg University. Her main research interests are writing, literacy, professional development, and social 
media. Randahl is also a member of the strong research group ROSE (Research on Subject-Specific Education) at Karlstad University.

Christina Olin-Scheller is professor in Educational Work, Director of the research center CSL (Centre of Language and Literature in Education), and the strong research group ROSE (Research on Subject-Specific Education) at Karlstad University. Her main research interests are young people's reading and writing in a new media landscape as well as questions dealing with reading instruction and reading development. Olin-Scheller coordinates the Swedish National Literacy Network and participates in the Nordic research excellence centre QUINT, Quality in Nordic Teaching.

\section{References}

Bergviken Rensfeldt, A., Hillman, T., \& Selwyn, N. (2018). Teachers 'Liking' Their Work? Exploring the Realities of Teacher Facebook Groups. British Educational Research fournal, 44(2), 230-250. https://doi. org/10.1002/berj.3325

Bergöö, K. (2005). Vilket svenskämne? Grundskolans svenskämnen $i$ ett lärarutbildningsperspektiv. (Doctoral dissertation, Malmö högskola). Retrieved from https://portal.research.lu.se/portal/files/5679228/26631.pdf

Blikstad-Balas, M. (2018). Skrivediskurser i norskfaget - en analyse av hvordan norsklærere gir skriveoppgaver på åttende trinn. Nordic fournal of Literacy Research, 4(0), 1-19. https://doi.org/10.23865/njlr.v4.1020

Blikstad-Balas, M., Roe, A., \& Klette, K. (2018). Opportunities to Write: An Exploration of Student Writing During Language Arts Lessons in Norwegian Lower Secondary Classrooms. Written Communication, 35(2), 119-154. https://doi.org/10.1177/0741088317751123

Brandt, D. (2019). The problem of writing in mass education. Utbildning E Demokrati Tidskrift för didaktik och utbildningspolitik, 28(2), 37-54.

Clark, R. \& Ivanic, R. (1999). Editorial. Language Awareness, 8(2), 63-70. https://doi.org/10.1080/09658419908 667118

Duncan-Howell, J. (2010). Teachers making connections: Online communities as a source of professional learning. British fournal of Educational Technology, 41(2), 324-340. https://doi.org/10.1111/j.1467-8535. 2009.00953.x

Evensen, L. S. (2007). Hvordan ser vi på utvikling av skrivekompetanse? Som stadier, som sprang, som orkestrering? In S. Matre (Ed.), Utfordringar for skriveopplaring og skriveforskning $i$ dag (p. 14-23). Trondheim: Tapir akademisk forlag.

Grönte, V. (2013). Pennvässaren: dramaturgin som verktyg till bra berättelser (4th ed.). Lund: Studentlitteratur.

Gustafsson, I. (2013). www.lektion.se - din kollega på nätet: En studie av lektionsförslag för skrivundervisning $i$ skolämnet svenska (Licentiatavhandling). Umeå University.

Holmberg, P. \& Wirdenäs, K. (2010). Skrivpedagogik i praktiken: Textkedjor, textsamtal och texttypologier i tre svensklärares klassrum. Språk \& Stil (NF 20), 105-131.

Holten Kvistad, A., \& Smemo, J. (2015). Den gode skriveoppgaven? En studie av fellestrekk ved vellykkede skriveoppgaver fra Normprojektet. In H. Otnes (Ed.), A invitere elever til skriving: ulike perspektiver på skriveoppgaver. Bergen: Fagbokforlaget.

Ivanič, R. (2004). Discourses of Writing and Learning to Write. Language and Education, 18(3), $220-245$. https://doi.org/10.1080/09500780408666877

Ivanič, R. (2017). Round table on discourses of writing, and writer identity. Paper presented at the LITUM Symposium, Umeå, Sweden.

Janks, H. (2010). Literacy and power. London: Routledge.

Karlsson, A.-M. (2011). Great Divide, Social Practice eller Motivated Sign? Materiella, sociala och semiotiska perspektiv på skriftspråkande. Svenskans beskrivning, 31, 13-30.

Kelly, N. \& Antonio, A. (2016). Teacher peer support in social network sites. Teaching and Teacher Education, 56, 138-149. https://doi.org/10.1016/j.tate.2016.02.007

Krogh, E., \& Penne, S. (2015). Languages, Literatures, and Literacies: Researching Paradoxes and Negotiations in Scandinavian L1 Subjects. Introduction. L1 Educational Studies in Language and Literature (Online Edition), (15), 1-16. https://doi.org/10.17239/L1ESLL-2015.15.01.12 
Lambirth, A. (2016). Exploring children's discourses of writing. English in Education, 50(3), 215-232. https:// doi.org/10.1111/eie.12111

Lantz-Andersson, A., Peterson, L., Hillman, T., Lundin, M., \& Bergviken Rensfeldt, A. (2017). Sharing repertoires in a teacher professional Facebook group. Learning, Culture and Social Interaction, 15. https:// doi.org/10.1016/j.lcsi.2017.07.001

Liberg, C., Wiksten Folkeryd, J., \& af Geijerstam, Å. (2012). Swedish - An updated school subject? Education Inquiry, 3(4), 477-493. https://doi.org/10.3402/edui.v3i4.22049

Liljekvist, Y., van Bommel, J., \& Olin-Scheller, C. (2017). Professional Learning Communities in a Web 2.0 World: Rethinking the conditions for professional development. In I. H. Amzat \& N. P. Valdez (Eds.), Teacher empowerment toward professional development and practices: Perspectives across borders (269-280). Singapore: Springer Singapore.

Magnusson, J. (2018). Det diskursiva skrivandets funktion - en läromedelsanalys. Nordic Fournal of Literacy Research, 4, 22-41. https://doi.org/10.23865/njlr.v4.960

Magnusson, J. (2019). Läroboken och det diskursiva skrivandet: genrer, textaktiviteter och medierande redskap i läromedel för årskurs 1 till 3. Forskning om undervisning och lärande, 7(2), 67-94.

McCarthey, S. J., Woodard, R., \& Kang, G. (2014). Elementary Teachers Negotiating Discourses in Writing Instruction. Written Communication, 31(1), 58-90. https://doi.org/10.1177/0741088313510888

OECD. (2015). Education at a Glance 2015. Retrieved from http://www.oecd.org/education/education-at-aglance-2015.htm

Peterson, S. S, Parr, J., Lindgren, E., \& Kaufman. D. (2018). Conceptualizations of writing in early years curricula and standards documents: international perspectives. The Curriculum fournal, 29(4). https://doi.org/ $10.1080 / 09585176.2018 .1500489$

Peterson, S. S. (2012). An Analysis of Discourses of Writing and Writing Instruction in Curricula Across Canada. Curriculum Inquiry, 42(2), 260-284. https://doi.org/10.1111/j.1467-873X.2012.00589.x

Prestridge, S. (2019). Categorising teachers' use of social media for their professional learning: A self-generating professional learning paradigm. Computers $\mathcal{E}$ Education, 129, 143-158.

Randahl, A.-C. (2012). "Oftast är vi ganska fria”: eleverna, skrivandet och skrivundervisningen i tre gymnasieklasser (Licentiatavhandling, Gotheburg University). Retrieved from https:/gupea.ub.gu.se/handle/2077/30418

Randahl, A.-C., Olin-Scheller, C., van Bommel, J. \& Liljekvist, Y. (2017). Svensklärare på sociala medier: En ämnesdidaktisk analys av tre svensklärargrupper på Facebook. Tolfte nationella konferensen $i$ svenska med didaktisk inriktning. Textkulturer. Karlstad 24-25 nov, 2016. Karlstad: Centrum för språk- och litteraturdidaktik vid Karlstads universitet, s. 259-276. Retrieved from http://kau.diva-portal.org/smash/ record.jsf?pid=diva $2 \% 3 \mathrm{~A} 1169103 \&$ dswid $=8607$

Randahl, A-C. (2018). Språkhandlingar i professionella lärandegemenskaper på Facebook. Grammatik, kritik, didaktik. Nordiska studier $i$ systemisk-funktionell lingvistik och socialsemiotik (p. 117-127). Retrieved from http://hdl.handle.net/2077/56444

Ranieri, M., Manca, S., \& Fini, A. (2012). Why (and how) do teachers engage in social networks? British fournal of Educational Technology, September, 43(5), 754-769. https://doi.org/10.1111/j.1467-8535.2012.01356.x

Roberts, L. D. (2015). Ethical issues in conducting qualitative research in online communities. Qualitative Research in Psychology, 12(3), 314-325. https://doi.org/10.1080/14780887.2015.1008909

Selander, S. (2004). Pedagogiske tekster for kommunikasjon og lering. Oslo: Universitetsforlaget.

Smidt, J. (2010). Å bygge hus og mure, veier og bruer i skrift - Skrivning i morsmålsfaget og de andre fagene på skolen. In K. Adelmann (Ed.), Nationella konferensen i svenska med didaktisk inriktning. Att bygga broar. Kulturella, språkliga och mediala möten (p. 143-167). Uppsala: SMDI.

Solheim, R. \& Matre, S. (2014). Forventninger om skrivekompetanse. Viden om lcesning, 15(3), 76-89.

Stensson, H. (2016a). Fördel: SVA för nyanlända. Åk 4-6, Övningsbok. Stockholm: Natur \& kultur.

Stensson, H. (2016b). Fördel: Sva för nyanlända. Åk 4-6, Textbok. Stockholm: Natur \& kultur.

Stoll, L., Bolam, R., McMahon, A., Wallace, M., \& Thomas, S. (2006). Professional Learning Communities: A Review of the Literature. Fournal of Educational Change, 7(4), 221-258. https://doi.org/10.1007/s10833006-0001-8

Street, B. (1984). Literacy in theory and practice. New York: Cambridge University Press.

Sturk, E. \& Lindgren, E. (2019). Discourses in Teachers' Talk about Writing. Written Communication, 36(4), 503-537. https://doi.org/10.1177/0741088319862512

Walldén, R. (2019). Genom genrens lins: pedagogisk kommunikation i tidigare skolår. (Dissertation). Malmö Högskola, Sweden.

van Bommel, J., Randahl, A.-C., Liljekvist,Y., \& Ruthven, K. (2020). Tracing teachers' transformation of knowledge in social media. Teaching and Teacher Education, 87,102958. https://doi.org/10.1016/j.tate.2019.102958

Veum, A. (2015). Skriveoppgåver i utvikling? (Vol. Å invitere elever til skriving: ulike perspektiver på skriveoppgaver). Bergen: Fagbokforlaget. 


\section{E. Sturk, A.-C. Randahl E C. Olin-Scheller}

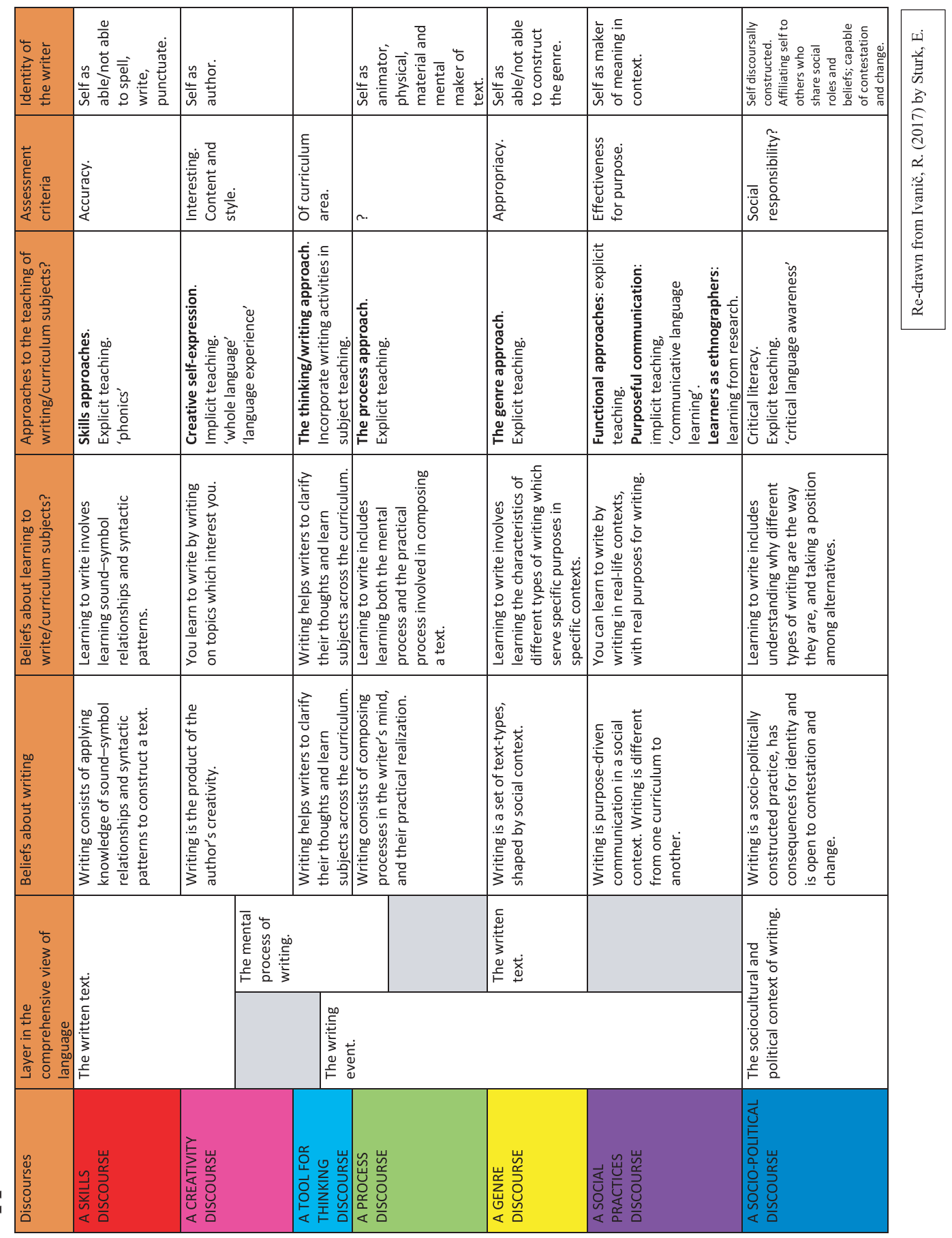




\section{Appendix 2}

\begin{tabular}{|c|c|c|}
\hline Title & Publishers & Author/s \\
\hline$A B C-$ klubben $^{\star}$ & Natur och kultur & $\begin{array}{l}\text { Felth Sjölund, I., Hed Andersson, P., Persson, S., } \\
\text { Wänblad, M. }\end{array}$ \\
\hline $\begin{array}{l}\text { Att lära sig stava rätt - } \\
\text { på ett enkelt och roligt sätt }\end{array}$ & Studentlitteratur & Jähnke Johnsson, P \\
\hline Briljant svenska ${ }^{\star}$ & Gleerups & Emanuelsson, B., Gardell, L., Wikström, B. \\
\hline Bron & Sanoma & Guvå, L., Peña, C. \\
\hline Den magiska dörren & (digital) & Sahlin, J. \\
\hline Ett halvt ark papper & Mediateket (digital) & Söder, E. \\
\hline Ett skepp kommer lastat ${ }^{\star}$ & Liber & Mattson, K., Widmark, M. \\
\hline Forma språket ${ }^{\star}$ & Gleerups & Hultén, R. \\
\hline $\begin{array}{l}\text { Fördel SVA för } \\
\text { nyanlända* }\end{array}$ & Natur och kultur & Sahlin, P., Stensson, H., Svensson, J. Ill: Reuterskiöld, S. \\
\hline Förstagluttarna & Natur och kultur & $\begin{array}{l}\text { Annell, B., Håkansson, G., Lundberg, I., Nilsson, M., } \\
\text { Nilsson, S. }\end{array}$ \\
\hline Klara, färdiga, $g a^{\star}$ & Natur och kultur & Anderson, L., Bengtén, B., Nordling, E. \\
\hline Kom i gång!* & Natur och kultur & Lyberg Mogensen, A., Wewel, A. \\
\hline Läs med oss ${ }^{\star}$ & Natur och kultur & $\begin{array}{l}\text { Annell, B., Benoit, M., Berling, B., Korsell, I., Lundberg, } \\
\text { I., Malmborg, E., Westman, L. }\end{array}$ \\
\hline Pennvässaren & Studentlitteratur & Grönte, V. \\
\hline Portal svensk $a^{\star}$ & Gleerups & Bohlin, S., Brunosson, C., Greczanik, L., Johansson, M. \\
\hline Prima svenska & Gleerups & Eskilsson, U., Hultén, R., Johannesson, M. \\
\hline Läsdax! Skrivdax!* & Sanoma utbildning & Bross, H., Hansen, A., Rosvall, C. \\
\hline Språkis ${ }^{\star}$ & Liber & Eriksson, H., Göthner, E., Ölwegård, Å. \\
\hline Språkkul & Studentlitteratur & Johansson, A., Jonsson, A.-S., Ring, C. \\
\hline Språkskrinet ${ }^{\star}$ & Majema & $\begin{array}{l}\text { Anckarman, L., Billström, M., Björnekull, C., Härdin, S., } \\
\text { Lindén, J., Mårtensson, A., Neiman Hedensjö, K. }\end{array}$ \\
\hline Svenskbiten ${ }^{\star}$ & Gleerups & Aspelin, M., Carlsson, E. \\
\hline Tala med texten ${ }^{\star}$ & Gleerups & Roos, J. \\
\hline Upptäck orden & Sanoma & Klintenberg, B. \\
\hline
\end{tabular}

*= a series of school books have been analysed. 


\section{E. Sturk, A.-C. Randahl E C. Olin-Scheller}

\section{Appendix 3}

Scale for discourse analysis of school books.

4 Dominating discourse: Congruency between explicit expressed discourse and implicit expressed discourse, found in exercises. Congruency between dimensions (columns) of the current discourse.

3 Supportive discourse: Congruency between explicit expressed discourse and implicit expressed discourse, found in exercises, though not dominant ... Does not meet all dimensions of the current discourse.

2 Implicit discourse: Frequently present in single exercises.

1 Single discourse: Found in single exercises.

0 Lack. 